\title{
Diversity and conservation of European dragonflies and damselflies (Odonata)
}

\author{
Vincent J. Kalkman • Jean-Pierre Boudot • Rafał Bernard • Geert De Knijf • \\ Frank Suhling $\cdot$ Tim Termaat
}

Received: 8 June 2017/Revised: 17 December 2017/ Accepted: 23 December 2017/Published online: 18 January 2018

(C) The Author(s) 2018. This article is an open access publication

\begin{abstract}
Based on a distribution database brought together for the recently published Atlas of the European dragonflies and damselflies, we describe the patterns of diversity and endemism of these insect groups. Highest species richness, as well as richness of predominantly lentic species, occurs in central and western-central Europe. Strictly lotic species have their centre of diversity in southwest France and parts of the Iberian Peninsula. The highest number of endemic species is found in southwest France, the
\end{abstract}

Handling editor: Eric R. Larson

Electronic supplementary material The online version of this article (https://doi.org/10.1007/s10750-017-3495-6) contains supplementary material, which is available to authorized users.

V. J. Kalkman ( $\square)$

European Invertebrate Survey/Naturalis Biodiversity

Center, The Netherlands, P.O. Box 9517,

2300 RA Leiden, The Netherlands

e-mail: Vincent.kalkman@naturalis.nl

\section{J.-P. Boudot}

Société Française d'Odonatologie, Immeuble Orphée, Apt

703, 78 rue de la Justice, 54710 Ludres, France

e-mail: jean.pierre.boudot@numericable.fr

\section{R. Bernard}

Department of Nature Education and Conservation, Adam

Mickiewicz University in Poznań, Umultowska 89,

61-614 Poznań, Poland

e-mail: rbernard@amu.edu.pl
Iberian Peninsula and the Balkan Peninsula. A comparison of the diversity patterns of Odonata species listed in the EU Habitats Directive with those listed in the European Red List highlights a strong mismatch between species threatened in Europe, which are mainly found in the Mediterranean, and species legally protected by the European Union, which are concentrated in central and western Europe. This mismatch has a historical origin, as the species listed in the Habitats Directive were mostly selected in the 1970s and 1980s when water quality in western and central Europe was poor. Since the 1990s, water and habitat quality has improved in these parts of Europe while in the same period the pressure on aquatic habitats in the Mediterranean has increased greatly.

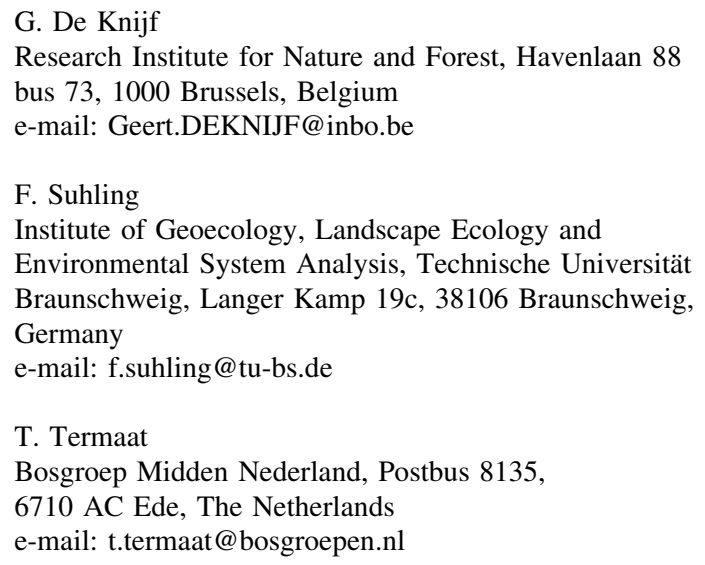


Keywords Zygoptera - Anisoptera - IUCN Red List . Habitats Directive $\cdot$ Endemic species

\section{Introduction}

Dragonflies and damselflies have a strong appeal to the general public and have become increasingly popular with amateur naturalists over the last two decades. This has resulted in a substantial increase in the availability of distribution data and in a steady flow of publications of international, national and regional Red Lists, distribution atlases and, recently, a distribution atlas covering the whole European continent (Boudot \& Kalkman, 2015). Over the same period, the number of academic publications studying the distribution patterns of dragonflies and damselflies in Europe has also increased. Examples include several macroecological and biogeographical studies, for instance exploring the boundary between the Palaearctic and the Oriental region (Heiser \& Schmitt, 2013), defining species richness patterns (Keil et al., 2008) and, particularly, examining ranges and range shifts (Hof et al., 2006, 2012; Grewe et al., 2012). Most of these studies were not based on geo-referenced data but instead used digitised outline distribution maps published by Askew (1988) and Dijkstra \& Lewington (2006). These maps are hand drawn and have obvious limitations for detailed distribution analyses. The accuracy of the maps in Askew (1988) is limited by the near absence of distribution data from parts of the Mediterranean at the time of publication, and by the distribution data for eastern Europe being largely inaccessible to the author. The maps published by Dijkstra \& Lewington (2006) are based on a far greater amount of data, but necessarily show a simplification of the patterns as they were meant for printing at a size of $5 \times 5 \mathrm{~cm}$ only. The results and conclusions of publications that used these maps as source data might be largely acceptable, but are in need of validation using proper distribution data.

Odonata also play a central role in the conservation of freshwater habitats (Clausnitzer et al., 2009). Many European countries have produced their own Red Lists for odonates (e.g. Sahlén et al., 2004; De Knijf et al., 2015; Ott et al., 2015). However, in several countries, the Red Lists have no legal status and do not result in an efficient protection of dragonflies and their habitats.
By far, the most important legal protection of dragonflies and their habitats is offered by the European Habitats Directive (Council Directive 92/43/EEC). This Directive was implemented in 1994 and is in place in all 28 member states of the European Union (De Knijf et al., 2015). The Annexes of this Directive list species that are protected throughout the European Union, and member states have an obligation to designate Special Areas of Conservation for species mentioned in Annex II, while species listed in Annex IV are strictly protected throughout their range. The selection of species included in the Habitats Directive was primarily based on a list drafted in the late 1970s for the Bern Convention, and since then only a small number of species have been added by new member states.

A database with distribution data for all European odonates was assembled during the publication of the Atlas of the European damselflies and dragonflies (Boudot \& Kalkman, 2015), and here we use this database for two purposes. Firstly, we present an overview of the distribution of species richness within Europe for odonates of lentic and lotic habitats and of species endemic to Europe. Secondly, we compare the distribution of species in the EU Habitats Directive with those species listed as threatened in the European Red List of Dragonflies (Kalkman et al., 2010), in order to test if the Habitats Directive currently provides the protection of those species and habitats which are most under pressure.

\section{Materials and methods}

The maps presented here are based on information held in the database created for the Atlas of the European dragonflies and damselflies (Boudot \& Kalkman, 2015), in which the eastern border of Europe is defined through the Ural Mountains, the lower Volga valley and the Caspian Sea. Also included into Europe are the Canary Islands and Madeira, the Azores, Cyprus and all the Greek and Turkish Aegean Islands. Our paper is based on distribution records of all 143 species known to occur in Europe; a complete list of these is given in Online Resource 1. Doubtful records, e.g. records of species far outside their known area of distribution and unsupported by evidence, are excluded, as are records of non-native dragonflies or damselflies, since none are known to breed in Europe 
under natural conditions. The European database was created by combining national databases from all European countries (for details see Boudot \& Kalkman, 2015). The overwhelming majority of data has been collected by citizen scientists. Due to the availability of good field guides and determination keys, the well-organised communities of volunteers and the long history of the study of odonates through amateurs, the identifications made by citizen scientists are of equal quality as those of professionals. The content of the national databases varied and although most national databases contained point data some included only presence-absence data for 50 by $50 \mathrm{~km}$ squares. In total over five million records were available which represent 51.350 confirmed presences (a species in a 50 by $50 \mathrm{~km}$ square) from in total 2,829 $50 \times 50 \mathrm{~km}$ UTM grid squares before 1990 and 74.480 confirmed presences from in total 2,828 $50 \times 50 \mathrm{~km}$ UTM grid squares from 1990 onwards. Large regions of eastern Europe but also parts of Spain and Italy were poorly explored prior to 1990 for which reason we do not use the database to analyse changes over time. The maps depict the regional diversity of species from 1990 onwards based on 50 x $50 \mathrm{~km}$ UTM grid squares which is the most commonly used grid size for depicting the European distribution of plants and animals (e.g. Mitchell-Jones et al., 1999; Sillero et al., 2014). With the exception of Belarus, Russia and the Ukraine most regions have been well explored so that the maps properly reflect the general distributions of the individual species.

The accuracy of an estimate of species richness for each square is dependent on the sampling effort, and ideally one would perform rarefaction analyses to test whether sampling effort is sufficient for each square (Donald \& Fuller, 1998; Dennis \& Thomas, 2000; Gotelli \& Colwell, 2001). However, the over fifty different regional and national databases from which the European database was derived varied greatly in their content, with some of them merely containing information on the presence/absence for each square, making it impossible to perform rarefaction. The diversity maps we present will thus likely be influenced by sampling effort. However, we believe that this, with the exception of Belarus, Russia and the Ukraine, does not impact the general patterns shown by the maps.

In the present publication, we have analysed and plotted the total species diversity per grid square, as well as the diversity of lotic, lentic, endemic and threatened species, all based on records from 1990 onwards.

The 143 species in the database were divided into a lentic and a lotic group. Species occurring in both lotic and lentic situations were included in the lentic group so that the lotic group only includes species strictly dependent on habitats with running water. The division was based on expert judgement by the authors and is in line with information on habitats provided by Boudot \& Kalkman (2015). This division of the 143 species according to their habitat preference resulted in a list of 44 species classified as strictly lotic and 99 species classified as predominantly lentic (Online Resource 1). For the mapping of European endemics (16 species), a list was made of all species only occurring in the European area as defined above (Online Resource 1); range-restricted species with some occurrences in the Maghreb or Southwest Asia were not considered endemic to Europe. For the map of species diversity covering species of the Habitats Directive (16 species), all species listed in Annex II and Annex IV were included (De Knijf et al., 2015). The list of species considered to be threatened in Europe ( 19 species) is based on the Red List of Europe (Kalkman et al., 2010), which was published by International Union for Conservation of Nature (IUCN) in collaboration with the European Union, and includes species listed as Vulnerable, Endangered or Critically Endangered.

The database used for the Atlas of the European dragonflies and damselflies consists of over fifty regional or national databases which together cover the whole continent. A simplified database showing the distribution of each species in each 50 x $50 \mathrm{~km}$ UTM square both before and after 1990 is available for further analyses (Online Resource 2).

\section{Results}

\section{Species diversity}

Areas with a high total species diversity are centred in France, Germany and the Alps (Fig. 1). The grid squares with the highest numbers of species (64 to 66 species) are found in Austria (3 squares), France (3), Germany (6) and Switzerland (2). The diversity of strictly lotic species is at its greatest in southwest 


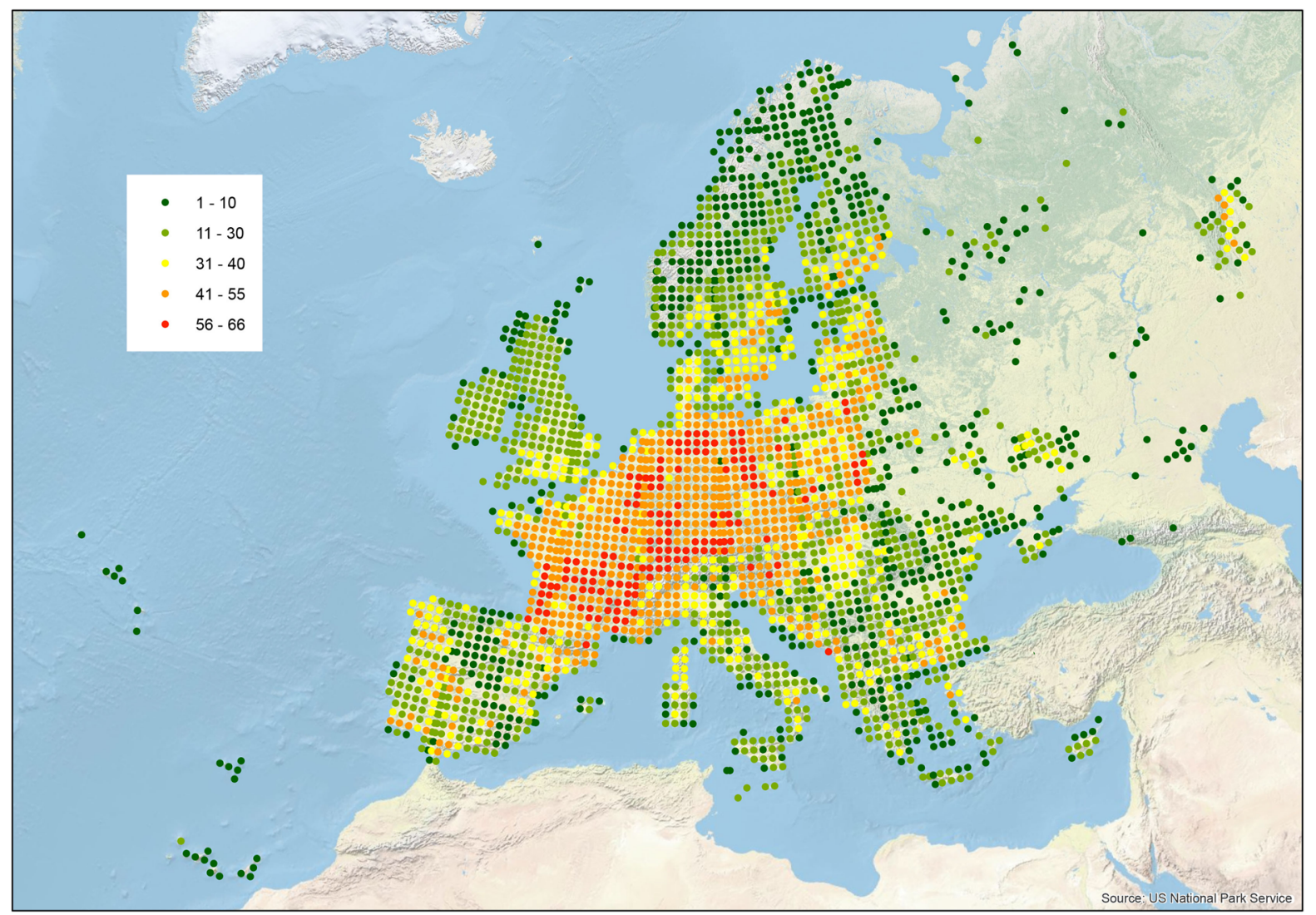

Fig. 1 Diversity map of the 143 European dragonfly species

Europe (Fig. 2), with strong concentrations in the south-western half of France and parts of the Iberian Peninsula. Species found predominantly in lentic habitats (Fig. 2) reach their highest diversity in rather more northerly regions, in central and eastern Europe.

Patterns of endemism

The diversity of species endemic to Europe (16 species) was found to be highest in the Iberian Peninsula and southern France (Fig. 3), where up to seven species endemic to Europe can be found in a single 50 x $50 \mathrm{~km}$ square. Another concentration of endemics was found in the southern Balkan region, where five species endemic to Europe are found in mainland Greece and adjacent countries, while Crete holds another two different endemics. Many of the endemic species found in the Iberian Peninsula and southern France range widely across this region, whereas those found in the southern Balkan region tend to have small, non-overlapping ranges (Fig. 3).
Due to this, four to seven endemics are found in many of the 50 x $50 \mathrm{~km}$ squares in the Iberian Peninsula and southern France, while at most three co-occur in squares situated in the southern Balkan region.

Hardly any endemics were found outside the Mediterranean region and southern France, with only the largely western European Gomphus pulchellus reaching western-central Europe, Cordulegaster heros reaching southern central Europe and Cordulegaster bidentata being largely restricted to hilly regions and mountains in central and eastern Europe; $C$. bidentata is the only species endemic to Europe that has its main centre of distribution in central Europe.

\section{Diversity patterns of threatened species}

Sixteen of the 143 European species are listed in the Habitats Directive, and these were found to have their distributions clearly concentrated in western, central and north-eastern Europe (Fig. 4). By contrast, the 19 species listed as threatened in the European Red List 

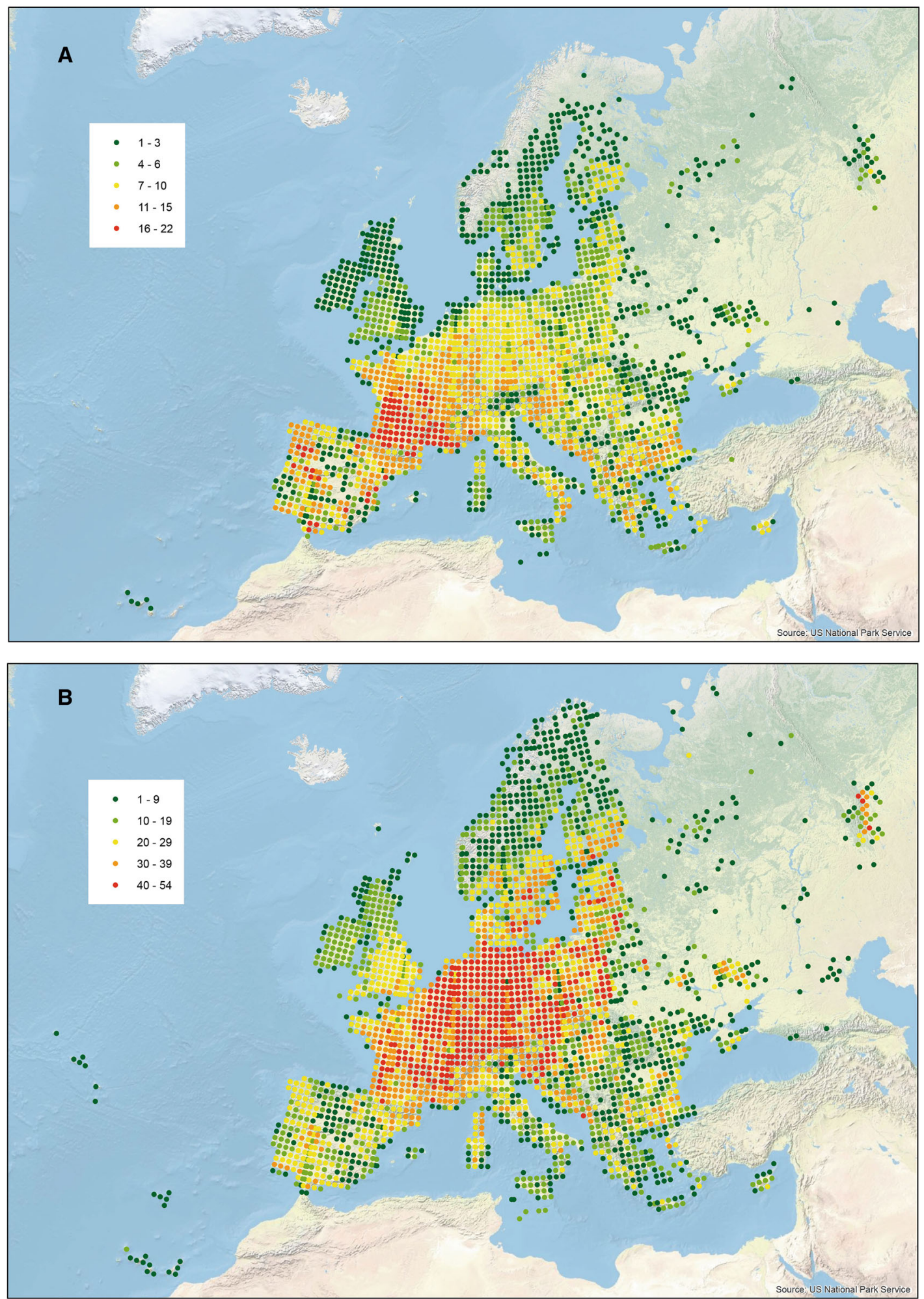

Fig. 2 Diversity of lotic and lentic species of dragonflies: A diversity map of the 44 species predominantly breeding in lotic habitats; B diversity map of the 99 species breeding in lentic habitats or commonly found in both lotic and lentic habitats 
were mostly found to occupy southern Europe, with particular concentrations in Greece and the Iberian Peninsula (Fig. 4). Only two of these threatened species extend significantly outside the Mediterranean region, with populations of Lestes macrostigma occurring on the French Atlantic coast, in the Pannonian Plain and in southern Russia, while Sympetrum depressiusculum occurs widely across large parts of eastern, central and western Europe.

\section{Discussion}

Species diversity patterns

The diversity maps (Fig. 1) show clearly that the diversity increases going from northern Europe to the south of central Europe which is likely to be correlated with temperature. The drop in diversity in the Mediterranean region is caused by the absence of many lentic species (Fig. 2) which may correlate with lower rainfall resulting in large permanent marshlands becoming scarce, while other types of habitat such as bogs and fenland are largely absent. Species restricted to these habitats largely dominate the fauna in central Europe, but are missing from most of the Mediterranean.

The species richness pattern of dragonflies in Europe and North Africa was studied in detail by Keil et al. (2008), who found it agreeing with the waterenergy hypothesis, which states that in the north where water is broadly available the limiting factor is the energy input, whereas in the warmer and drier south species richness is limited by the availability of water. In addition to these broad-scale factors, the presence of mountains results in regional peaks in diversity, as it allows species of bogs and fenlands to co-occur with species of a predominantly Mediterranean distribution in the same $50 \times 50 \mathrm{~km}$ square. These species are not syntopic as they are found in different habitats at different elevations, but their near co-occurrence means, for instance, that the border areas of the Alps are among the species richest regions in Europe.

The diversity of dragonflies and damselflies in the Western Palaearctic is relatively low, not only when compared to tropical regions but also when compared to the Nearctic region and to the Eastern Palaearctic (Suhling et al., 2015). This is believed to result from the ice cap during the last Ice Age glaciations stretching relatively far southwards in Europe, and the west-to-east oriented barriers (the Pyrenees, Alps, Carpathians, the Mediterranean Sea and the Sahara Desert) limiting the possibility for species to shift their ranges northwards or southwards during climate oscillations (Hewitt, 2000). The Sahara and Mediterranean Sea also form barriers limiting the expansion of Afrotropical species into the southern Mediterranean countries and hence further into Europe. The distributions of some species endemic, or near endemic, to Europe suggest that a part of the pre-glacial European fauna survived the glaciations in refugia in the Iberian Peninsula, southern Italy, the Balkans or in parts of southwest Asia (St Quentin, 1960; Dévai, 1976; Sternberg, 1998). In some cases, isolation was long enough to allow for speciation, with populations from different refugia remaining separate even after their ranges met again as a result of postglacial expansion. These ideas agree well with the overall diversity pattern of dragonflies endemic to Europe presented here (Fig. 3). The small number of molecular studies available (Sadeghi et al., 2010; Froufe et al., 2013; Guan et al., 2013; Ferreira et al., 2015; De Knijf et al., 2016; Schneider et al., 2016) also conform with these patterns, but as none of the studies provide detailed timescale information, it is not certain whether patterns evolved due to isolation induced by glacial periods, or are the result of parapatric speciations induced by, for instance, different climatic conditions at both ends of a species' range.

The diversity patterns shown by strictly lotic species (Fig. 2) and by lentic species (Fig. 2) are strikingly different, with the former having their diversity optimum in the Mediterranean while the diversity of lentic species is centred around central and western Europe. Hof et al. (2006) stressed that lotic species on average have smaller ranges, which they explained by their supposed lower dispersal ability. However, while we agree that lentic species on average have a stronger dispersal ability, the ability of dispersal and colonisation of lotic species is still such that they can easily expand their range over tens of kilometres when habitat conditions are suitable. This is evidenced by the recent rapid expansion of several lotic species (Calopteryx splendens, Gomphus flavipes, G. vulgatissimus, Ophiogomphus cecilia) into areas of Europe where they had previously become extinct (e.g. Boudot \& Dyatlova, 2015; Boudot et al., 2015; Kalkman \& Ambrus, 2015), and by the 

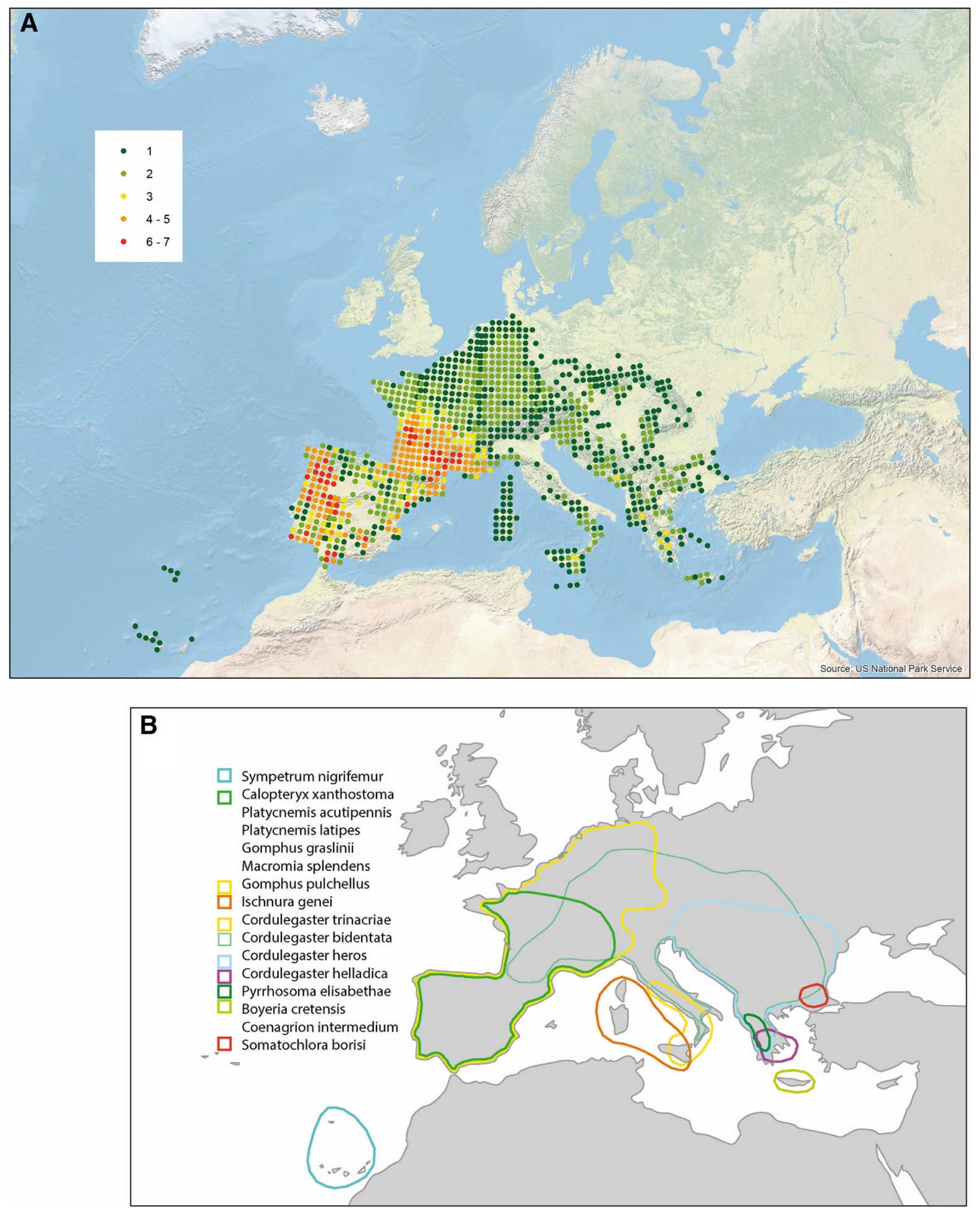

Fig. 3 Distribution of endemic European dragonflies: A diversity map of the 16 species endemic to Europe; B distribution of the 16 species endemic to Europe 

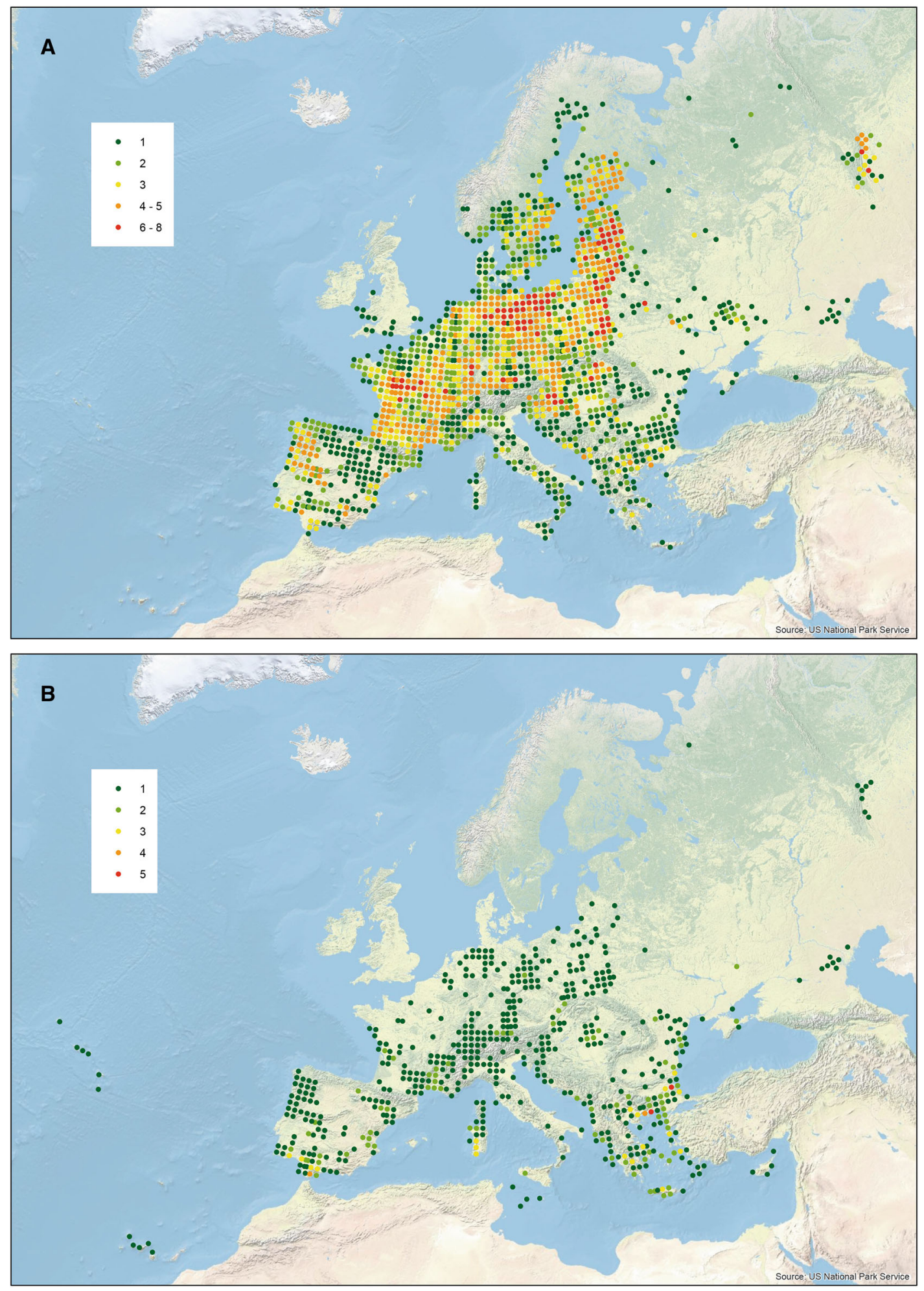

Fig. 4 Species diversity according to conservation status: A diversity map of the 16 species listed in the European Habitats Directive; B diversity map of the 19 species listed as Vulnerable, Endangered or Critically Endangered in the European Red List 
expansion of some lotic species into areas where they had previously been absent (e.g. Cordulegaster boltonii in northern Sweden and Gomphus flavipes in southern Finland; Hickling et al., 2005; Van Strien et al., 2013; Boudot \& Dyatlova, 2015; Boudot \& Kalkman, 2015; Termaat et al., 2015). The idea that the relative scarceness of strictly lotic species in northern and central Europe can be explained solely by their failure to expand northwards following the last glaciations therefore in our opinion seems unlikely. A better explanation for the more southerly peak in diversity found in strictly lotic species is simply that dragonflies reach their highest diversity in warmer regions, and as running waters follow the air temperature less closely than standing waters and are therefore on average colder than such waterbodies (Maitland, 1990), the optimum for diversity will also be more southerly. This agrees with the fact that strictly lotic species that are able to persist in cooler regions of Europe generally do have wide ranges, often occurring eastwards into central Asia (e.g. Calopteryx splendens, Platycnemis pennipes) or Siberia (e.g. Gomphus flavipes, G. vulgatissimus, Ophiogomphus cecilia).

Grewe et al. (2012) analysed the changes in ranges of species by comparing the maps of Askew (1988) with those of Dijkstra \& Lewington (2006) and reached the conclusion that only species occurring predominantly in standing waters have shown a marked northwards expansion over the last few decades. They explained this by arguing that lentic species have higher dispersal abilities than those restricted to running water habitats, as an adaption to the lower spatial and temporal persistence of lentic habitats. While we agree that there is a difference in dispersal ability between species of lentic or lotic habitats, this alone-in our opinion-cannot explain the scarcity of recent northward expansions by lotic species. There are three other reasons which together might explain the comparatively rather weak northerly range expansions: (1) these species are mostly habitat specialists, and some areas containing the required types of lotic habitats (e.g. streams and rivers dominated by coarse sediments) might not be colonised due to the lack of stepping stone habitats in the intervening areas, (2) species of lotic habitats are under pressure in large parts of the Mediterranean, which is likely to hamper their capacity to expand their ranges, and (3) species of running waters have (largely) non-overlapping ranges, many being replaced to the north by closely related species which may restrict their possibilities for northerly range expansion. This last situation is true for nine of the 44 strictly lotic species in Europe, while it occurs in only two (both Ischnura) of the 99 predominantly lentic species. Examples include the largely Iberian Calopteryx xanthostoma which is bordered to the north by $C$. splendens, and five species of Cordulegaster which are bordered by other closely related species all around their range.

Fourteen of the 16 species endemic to Europe are restricted to running waters and the diversity pattern of endemics therefore resembles the pattern of the strictly lotic species. Of these sixteen species, four are island endemics with closely related species on the mainland, suggesting that they diverged from a common ancestor due to isolation. Eleven endemic species are all clearly centred on one of the three peninsulas in the south of Europe: the Iberian Peninsula including southern France (six species), Italy (one species) or the Balkans (four species), suggesting that they found refuge in these areas during the last glaciation.

The pattern of total diversity of dragonflies is clearly different from the patterns shown by three other well-studied aquatic insect groups: stoneflies (Plecoptera), caddisflies (Trichoptera) and mayflies (Ephemeroptera). In dragonflies, the total diversity is centred around central Europe while in stoneflies, caddisflies and mayflies, the highest diversity is found in the Mediterranean Peninsulas (Fochetti \& Tierno de Figueroa, 2006; Conti et al., 2013; Schmidt-Kloiber et al., 2017). The area with the highest diversity of dragonflies is centred in the Alps which is also among the richest areas for stoneflies and caddisflies (Fochetti \& Tierno de Figueroa, 2006; Schmidt-Kloiber et al., 2017). In dragonflies, this high diversity is caused by the co-occurrence of Mediterranean species in the lowland and more boreal species at higher altitudes within a single grid cell; the mountains themselves are not that rich in dragonflies. This is clearly different from stoneflies and caddisflies where the main diversity is clearly concentrated in small streams and springs at higher altitudes.

\section{Conservation}

Hotspots of threatened species are found in Crete (2 species), the southern part of the Balkan Peninsula (9 
species) and the Iberian Peninsula and southern France (4 species). The species found in the Balkan Peninsula have small ranges that often do not overlap with those of the other threatened species in the area, and hence the high overall number of threatened species in the Balkan Peninsula does not fully stand out on the map (Fig. 4). The preponderance of Mediterranean species identified as at threat in the European Red List is caused by the fact that, while the decline of most species in the northern two-thirds of Europe had halted by the time that the Red List was drafted (De Knijf et al., 2015; Ott et al., 2015; Termaat et al., 2015), the condition of Mediterranean freshwater habitats continues to deteriorate due to land conversion, water pollution, construction of dams, increased demand for freshwater and increased periods of drought linked to climate change (Darwall et al., 2014). In addition, many Mediterranean species have relatively small distribution ranges, while those occurring in the northern two-thirds of Europe are often wide ranging and thus less likely to meet the IUCN criteria for inclusion in a threat category. Twelve of the 16 threatened Mediterranean species are found in running waters, and the decrease in water flow and water quality of brooks and rivers is the main cause of their decline (Riservato et al., 2009).

Of the 16 species listed in the EU Habitats Directive, 14 were already included in the list prepared in the 1970s and 1980s for the Bern Convention, and despite the expansion of the European Union, only two (Coenagrion ornatum and Cordulegaster heros) have been added since. Most of the species had been in decline during large parts of the $20^{\text {th }}$ century and some, such as Gomphus flavipes and Leucorrhinia caudalis, became very rare or even extinct in many areas of their former range. This decline was largely caused by the destruction of habitats, mismanagement of water courses and by water eutrophication and acidification due to domestic, agricultural and atmospheric pollution. These threats were strongest and most swiftly detected in western and western-central Europe, and had the greatest impact on species with a preference for either running or mesotrophic habitats (Termaat et al., 2015). Due to this, species occurring in these habitat types in these parts of Europe were overrepresented in the species listed in the Bern Convention and the Habitats Directive. Since the 1990s, improved sewage treatment and better regulation of industrial and agricultural emissions has led to a great improvement in water quality in western and central Europe, which has in turn been followed by a halt of decline of most species and even a clear recovery of some species (e.g. Gomphus flavipes and Leucorrhinia caudalis). Consequently, only three of the 16 species listed in the Habitats Directive are currently considered threatened at the European scale according to the 2010 European Red List (Kalkman et al., 2010). The overlap of Odonata species listed in the Habitats Directive and species currently considered to be threatened is small, and comprises only 3 of the 32 species in total. In addition, the geographical overlap of these two sets of species is also small. Whereas the species of the Habitats Directive are predominantly found in western and central Europe, the species currently considered as threatened in the European Red List are centred in the Mediterranean region. This geographic mismatch between protected species (i.e. listed in the Habitats Directive) and threatened species (listed in the Red List) had already been noticed by Cardoso (2012), who in addition showed that this was true not only for dragonflies but also for many other invertebrates, including butterflies (Van Swaay et al., 2010).

We judge that the species currently listed in the Habitats Directive are good indicators of the habitat quality of threatened habitat types. It seems that their inclusion in the Habitats Directive has helped their recovery and ensured the protection of their habitats. These species are indicators of habitat integrity and should remain listed in the Annexes, even if most are no longer threatened. However, the above-described mismatch between species of the Habitats Directive and the threatened species means that the strong legal protection offered by the Habitats Directive does not protect the currently threatened species. In order to overcome this bias, and to secure a good legal protection of European freshwater habitats, it is necessary to expand the current Annexes of the Habitats Directive to include species listed as threatened on the European Red List. The Habitats Directive states that species can be listed in Annex II or IV if, within the EU, they are either (1) Endangered, (2) Vulnerable but declining and likely to move into the Endangered category in the near future, (3) rare, i.e. with small populations presently not Endangered or Vulnerable, but which are at risk, or (4) endemic and requiring special attention because of the specific nature of their habitat (see Habitats Directive for full 
Table 1 Recommendation of European dragonfly and damselfly species to be added to the species already listed in the Habitats Directive

\begin{tabular}{|c|c|c|c|c|}
\hline Species & $\begin{array}{l}\text { Status on European Red List, } \\
\text { when different the status for } \\
\text { the } 27 \text { EU-member states is } \\
\text { given between brackets }\end{array}$ & $\begin{array}{l}\text { Endemic } \\
\text { to } \\
\text { Europe }\end{array}$ & European range & Rationale for inclusion \\
\hline Lestes macrostigma & Vulnerable (Endangered) & No & $\begin{array}{l}\text { Largely restricted to } \\
\text { Mediterranean and } \\
\text { Pannonian Plain }\end{array}$ & $\begin{array}{l}\text { Declining, relatively low number } \\
\text { of populations and depending on } \\
\text { a rare/threatened habitat type }\end{array}$ \\
\hline Nehalennia speciosa & Near Threatened (Vulnerable) & No & $\begin{array}{l}\text { Central and Eastern } \\
\text { Europe, has become } \\
\text { very rare in large } \\
\text { parts of its range }\end{array}$ & $\begin{array}{l}\text { Declining, relatively low number } \\
\text { of populations and depending on } \\
\text { a rare/threatened habitat type }\end{array}$ \\
\hline $\begin{array}{l}\text { Sympetrum } \\
\text { depressiusculum }\end{array}$ & Vulnerable & No & $\begin{array}{l}\text { Southern and central } \\
\text { Europe }\end{array}$ & $\begin{array}{l}\text { Declining, relatively low number } \\
\text { of populations and depending on } \\
\text { a rare/threatened habitat type }\end{array}$ \\
\hline Cordulegaster insignis & Endangered & No & $\begin{array}{l}\text { Southeastern parts of } \\
\text { Balkan Peninsula }\end{array}$ & $\begin{array}{l}\text { Declining, decrease in quality of } \\
\text { running waters throughout its } \\
\text { area of distribution }\end{array}$ \\
\hline Cordulegaster picta & Vulnerable & No & $\begin{array}{l}\text { Southeastern parts of } \\
\text { Balkan Peninsula }\end{array}$ & $\begin{array}{l}\text { Declining, decrease in quality of } \\
\text { running waters throughout its } \\
\text { area of distribution }\end{array}$ \\
\hline Cordulegaster helladica & Endangered & Yes & $\begin{array}{l}\text { Southern parts of } \\
\text { Balkan Peninsula }\end{array}$ & $\begin{array}{l}\text { Declining, decrease in quality of } \\
\text { running waters throughout its } \\
\text { area of distribution. Subspecies } \\
\text { kastalia is critically endangered }\end{array}$ \\
\hline Somatochlora borisi & Vulnerable & Yes & $\begin{array}{l}\text { Very small, southeast } \\
\text { Bulgaria, } \\
\text { northeasternmost } \\
\text { Greece and } \\
\text { European Turkey }\end{array}$ & $\begin{array}{l}\text { Declining, decrease in quality of } \\
\text { running waters throughout its } \\
\text { area of distribution }\end{array}$ \\
\hline Onychogomphus costae & Endangered & No & Iberian Peninsula & $\begin{array}{l}\text { Declining, decrease in quality of } \\
\text { running waters throughout its } \\
\text { area of distribution }\end{array}$ \\
\hline Orthetrum nitidinerve & Vulnerable & No & $\begin{array}{l}\text { Iberian Peninsula, } \\
\text { Malta and parts of } \\
\text { Italy }\end{array}$ & $\begin{array}{l}\text { Declining, decrease in quality of } \\
\text { running waters throughout its } \\
\text { area of distribution }\end{array}$ \\
\hline Epallage fatime & Near Threatened & No & $\begin{array}{l}\text { Southern parts of } \\
\text { Balkan Peninsula }\end{array}$ & $\begin{array}{l}\text { Declining, decrease in quality of } \\
\text { running waters throughout its } \\
\text { area of distribution }\end{array}$ \\
\hline $\begin{array}{l}\text { Caliaeschna } \\
\text { microstigma }\end{array}$ & Near Threatened & No & $\begin{array}{l}\text { Southern parts of } \\
\text { Balkan Peninsula }\end{array}$ & $\begin{array}{l}\text { Declining, decrease in quality of } \\
\text { running waters throughout its } \\
\text { area of distribution }\end{array}$ \\
\hline Boyeria cretensis & Endangered & Yes & Crete & $\begin{array}{l}\text { Rare and declining, decrease in } \\
\text { quality of running waters } \\
\text { throughout its area of } \\
\text { distribution }\end{array}$ \\
\hline Coenagrion intermedium & Vulnerable & Yes & Crete & $\begin{array}{l}\text { Rare and declining, decrease in } \\
\text { quality of running waters } \\
\text { throughout its area of } \\
\text { distribution }\end{array}$ \\
\hline Ceriagrion georgifreyi & Critically Endangered & No & $\begin{array}{l}\text { Greece, not recorded } \\
\text { since } 1998\end{array}$ & $\begin{array}{l}\text { Very rare and declining, decrease } \\
\text { in quality of running waters } \\
\text { throughout its area of } \\
\text { distribution }\end{array}$ \\
\hline
\end{tabular}


Table 1 continued

\begin{tabular}{lllll}
\hline Species & $\begin{array}{l}\text { Status on European Red List, } \\
\text { when different the status for } \\
\text { the 27 EU-member states is } \\
\text { given between brackets }\end{array}$ & $\begin{array}{l}\text { Endemic } \\
\text { to } \\
\text { Europe }\end{array}$ & European range & Rationale for inclusion \\
\hline Pyrrhosoma elisabethae & Critically Endangered & Yes & Greece and Albania & $\begin{array}{l}\text { Very rare and declining, decrease } \\
\text { in quality of running waters } \\
\text { throughout its area of } \\
\text { distribution }\end{array}$ \\
\hline
\end{tabular}

text (Council Directive 92/43/EEC)). Species whose natural ranges are marginal within the EU and which are not endangered in the Western Palaearctic region are excluded. In Table 1, we propose new species that should be included in the Habitats Directive based on the above-mentioned criteria. It includes ten species which are either Vulnerable, Endangered or Critically Endangered on the European Red List of dragonflies. In addition, it includes two species (Epallage fatime, Caliaeschna microstigma) with a small European range, not currently placed in a threat category but which are declining and are likely to qualify for inclusion in the future. The three others proposed by us should be included in the Habitats Directive (Lestes macrostigma, Nehalennia speciosa and Sympetrum depressiusculum) have a wider European range but are declining and dependent on rare and threatened habitat types (e.g. Wildermuth \& Martens, 2014).

\section{Conclusions}

In this paper, we have discussed the diversity patterns of European dragonflies and damselflies with special focus on the origin of the differences in diversity pattern found between lentic and lotic species. More importantly, we showed that there is a strong mismatch between the distribution of species threatened according to the European Red List and species protected by the EU Habitats Directive. The highest number of threatened species is found in the Mediterranean region in habitats which receive little protection by European law. An evaluation of the list of species currently included in the EU Habitats Directive is needed to secure the effective protection of dragonflies and damselflies and their habitats in the future.
Acknowledgements Adrian Parr commented on the paper and kindly improved the English. Over the past few decades, thousands of volunteers have collected distribution data, and without their help this publication would have been impossible. We are also grateful for the time invested by the reviewers, their comments contributed strongly to the quality of the paper.

Open Access This article is distributed under the terms of the Creative Commons Attribution 4.0 International License (http:// creativecommons.org/licenses/by/4.0/), which permits unrestricted use, distribution, and reproduction in any medium, provided you give appropriate credit to the original author(s) and the source, provide a link to the Creative Commons license, and indicate if changes were made.

\section{References}

Askew, R. R., 1988. The Dragonflies of Europe. Harley Books, Colchester.

Boudot, J. P. \& E. Dyatlova, 2015. Gomphus flavipes. In Boudot, J.-P. \& V. J. Kalkman (eds), Atlas of the European Dragonflies and Damselflies. KNNV, Utrecht.

Boudot, J.-P. \& V. J. Kalkman (eds), 2015. Atlas of the Dragonflies and Damselflies of Europe. KNNV, Utrecht.

Boudot, J.-P., S. David \& D. Šácha, 2015. Gomphus vulgatissimus. In Boudot, J.-P. \& V. J. Kalkman (eds), Atlas of the European Dragonflies and Damselflies. KNNV, Utrecht.

Cardoso, P., 2012. Habitats Directive species lists: urgent need of revision. Insect Conservation and Diversity 5: 169-174.

Clausnitzer, V., V. J. Kalkman, M. Ram, B. Collen, J. E. M. Baillie, M. Bedjaniç, W. R. T. Darwall, K.-D. B. Dijkstra, R. Dow, J. Hawking, H. Karube, E. Malikova, D. Paulson, K. Schütte, F. Suhling, R. Villanueva, N. von Ellenrieder \& K. Wilson, 2009. Odonata enter the biodiversity crisis debate: the first global assessment of an insect group. Biological Conservation 142: 1864-1869.

Conti, L., A. Schmidt-Kloiber, G. Grenouillet \& W. Graf, 2013. A trait-based approach to assess the vulnerability of European aquatic insects to climate change. Hydrobiologia 721: 297-315.

Darwall, W., S. Carrizo, C. Numa, V. Barrios, J. Freyhof \& K. Smith, 2014. Freshwater Key Biodiversity Areas in the Mediterranean Basin Hotspot: Informing Species Conservation and Development Planning in Freshwater Ecosystems. IUCN, Cambridge. 
De Knijf, G., T. Termaat \& J. Ott, 2015. Conservation of European dragonflies and damselflies. In Boudot, J.-P. \& V. J. Kalkman (eds), Atlas of the Dragonflies and Damselflies of Europe. KNNV, Utrecht.

De Knijf, G., D. J. Sparrow, A. C. Dimitriou, R. Kent, H. Kent, K. Siedle, J. Lewis \& L. Crossley, 2016. Distribution, ecology and status of a threatened species Ischnura intermedia (Insecta: Odonata), new for Europe. International Journal of Odonatology 19: 257-274. https://doi.org/10. 1080/13887890.2016.1259662.

Dennis, R. L. H. \& C. D. Thomas, 2000. Bias in butterfly distribution maps: the influence of hot spots and recorder's home range. Journal of Insect Conservation 4: 73-77.

Dévai, G., 1976. The chorological research of the dragonfly (Odonata) fauna of Hungary. Acta Biologica Debrecina 13: 119-157.

Dijkstra, K.-D. B. \& R. Lewington, 2006. Field Guide to the Dragonflies of Britain and Europe. British Wildlife Publishing, London.

Donald, P. F. \& R. J. Fuller, 1998. Ornithological atlas data: a review of uses and limitations. Bird Study 45: 129-145.

Ferreira, S., J.-P. Boudot, M. El Haissoufi, P. C. Alves, D. J. Thompson, J. C. Brito \& P. C. Watts, 2015. Genetic distinctiveness of the damselfly Coenagrion puella in North Africa: an overlooked and endangered taxon. Conservation Genetics. https://doi.org/10.1007/s10592-0160826-5.

Fochetti, R. \& J. M. Tierno de Figueroa, 2006. Notes on diversity and conservation of the European fauna of Plecoptera (Insecta). Journal of Natural History 40: 2361-2369.

Froufe, E., S. Ferreira, J. P. Boudot, P. C. Alves \& D. J. Harris, 2013. Molecular phylogeny of the Western Palaearctic Cordulegaster taxa (Odonata: Anisoptera: Cordulegastridae). Biological Journal of the Linnean Society 111: 49-57.

Gotelli, N. J. \& R. K. Colwell, 2001. Quantifying biodiversity: procedures and pitfalls in the measurement and comparison of species richness. Ecology Letters 4: 379-391.

Grewe, Y., C. Hof, D. M. Dehling, R. Brandl \& M. Brändle, 2012. Recent range shifts of European dragonflies provide support for an inverse relationship between habitat predictability and dispersal. Global Ecology and Biogeography 22: 403-409.

Guan, Z., H. J. Dumont, X. Yu, B.-P. Han \& A. Vierstraete, 2013. Pyrrhosoma and its relatives: a phylogenetic study (Odonata: Zygoptera). International Journal of Odonatology 16: 247-257.

Heiser, M. \& T. Schmitt, 2013. Tracking the boundary between the Palaearctic and the Oriental region: new insights from dragonflies and damselflies (Odonata). Journal of Biogeography 40: 2047-2058.

Hewitt, G. M., 2000. The genetic legacy of the Quaternary ice ages. Nature 405: 907-913.

Hickling, R., D. B. Roy, J. K. Hill \& C. D. Thomas, 2005. A northward shift of range margins in British Odonata. Global Change Biology 11: 502-506.

Hof, C., M. Brändle \& R. Brandl, 2006. Lentic odonates have larger and more northern ranges than lotic species. Journal of Biogeography 33: 63-70.
Hof, C., M. Brändle, D. M. Dehling, M. Munguía, R. Brandl, M. B. Araújo \& C. Rahbek, 2012. Habitat stability affects dispersal and the ability to track climate change. Biology Letters 8: 639-643.

Kalkman, V. J. \& A. Ambrus, 2015. Ophiogomphus cecilia. In Boudot, J.-P. \& V. J. Kalkman (eds), Atlas of the European Dragonflies and Damselflies. KNNV, Utrecht.

Kalkman, V. J., J.-P. Boudot, R. Bernard, K. J. Conze, G. De Knijf, E. Dyatlova, S. Ferreira, M. Jović, J. Ott, E. Riservato \& G. Sahlén, 2010. European Red List of Dragonflies. Publications Office of the European Union, Luxembourg.

Keil, P., I. Simova \& B. A. Hawkins, 2008. Water-energy and the geographical species richness pattern of European and North African dragonflies (Odonata). Insect Conservation and Diversity 1: 142-150.

Maitland, P. S., 1990. Biology of Fresh Waters. Springer, Dordrecht.

Mitchell-Jones, A. J., G. Amori, W. Bogdanowicz, B. Kryštufek, P. J. H. Reijnders, F. Spitzenberger, M. Stubbe, J. B. M. Thissen, V. Vohralík \& J. Zima, 1999. The Atlas of European Mammals. Academic Press, London.

Ott, J., K. J. Conze, A. Günther, M. Lohr, R. Mauersberger, H.-J. Roland \& F. Suhling, 2015. Rote Liste und Gesamtartenliste der Libellen Deutschlands (Odonata). Libellula Supplement 14: 395-422.

Riservato, E., J. P. Boudot, S. Ferreira, M. Jović, V. J. Kalkman, W. Schneider, B. Samraoui \& A. Cuttelodd, 2009. The Status and Distribution of Dragonflies of the Mediterranean Basin. IUCN, Gland.

Sadeghi, S., T. Kyndt \& H. J. Dumont, 2010. Genetic diversity, population structure and taxonomy of Calopteryx splendens (Odonata: Calopterygidae): An AFLP analysis. European Journal of Entomology 107: 137-146.

Sahlén, G., R. Bernard, A. Cordero Rivera, R. Ketelaar \& F. Suhling, 2004. Critical species of Odonata in Europe. International Journal of Odonatology 7: 385-398.

Schmidt-Kloiber, A., P. J. Neu, M. Malicky, F. Pletterbauer, H. Malicky \& W. Graf, 2017. Aquatic biodiversity in Europe: a unique dataset on the distribution of Trichoptera species with important implications for conservation. Hydrobiologia 797: 11-27.

Schneider, T., D. Ikemeyer, S. Ferreira \& O. Müller, 2016. Rediscovery and redescription of Coenagrion persicum (Lohmann 1993) with description of the female, and some notes on habitat selection (Odonata: Coenagrionidae). Zootaxa 4103: 561-573.

Sillero, N., J. Campos, A. Bonardi, C. Corti, R. Creemers, P.-A. Crochet, J. Crnobrnja Isailovic, M. Denoël, G. F. Ficetola, J. Gonçalves, S. Kuzmin, P. Lymberakis, P. de Pous, A. Rodríguez, R. Sindaco, J. Speybroeck, B. Toxopeus, D. R. Vieites \& M. Vences, 2014. Updated distribution and biogeography of amphibians and reptiles of Europe. Amphibia-Reptilia 35: 1-31.

St Quentin, D., 1960. Die Odonatenfauna Europas, ihre Zusammensetzung und Herkunft. Zoologische Jahrbücher. Abteilung für Systematik, Geographie und Biologie der Tiere Jena 87: 301-316.

Sternberg, K., 1998. The postglacial colonisation of Central Europe by dragonflies, with special reference to southwestern Germany (Insecta, Odonata). Journal of Biogeography 25: 319-337. 
Suhling, F., G. Sahlén, S. Gorb, V. J. Kalkman, K.-D. B. Dijkstra \& J. Van Tol, 2015. Order Odonata. In Thorp, J. \& D. C. Rogers (eds), Ecology and General Biology: Thorp and Covich's Freshwater Invertebrates. Academic Press, San Diego: 893-932.

Termaat, T., R. H. A. Van Grunsven, C. L. Plate \& A. J. Van Strien, 2015. Strong recovery of dragonflies in recent decades in The Netherlands. Freshwater Science 34: 1094-1104.

Van Strien, A. J., T. Termaat, V. J. Kalkman, M. Prins, G. De Knijf, A.-L. Gourmand, X. Houard, B. Nelson, C. Plate, S. Prentice, E. Regan, D. Smallshire, C. Vanappelghem \& W.
Vanreusel, 2013. Occupancy modelling as a new approach to assess supranational trends using opportunistic data: a pilot study for the damselfly Calopteryx splendens. Biodiversity and Conservation 22: 673-686.

Van Swaay, C., A. Cuttelod, S. Collins, D. Maes, M. López Munguira, M. Šašić, J. Settele, R. Verovnik, T. Verstrael, M. Warren, M. Wiemers \& I. Wynhof, 2010. European Red List of Butterflies. Publications Office of the European Union, Luxembourg.

Wildermuth, H. \& A. Martens, 2014. Taschenlexikon der Libellen Europas: alle Arten von den Azoren bis zum Ural im Porträt. Quelle \& Meyer, Wiebelsheim. 